\title{
Globalisation, Logistics and Food Supply: Evidence from Vietnam
}

\author{
Duc Nha Le ${ }^{a}$ \\ Ton Duc Thang University
}

\begin{abstract}
Most countries satisfy domestic food consumption by importing from foreign supplies, thus highlighting the role of agricultural exports in maintaining and diversifying the global food supply. In the age of globalisation, whether the flourishing number of regional trade agreements (RTAs) has been facilitating greater market access of agricultural and food products is questioned by national governments. Meanwhile, logistics performance has been the bottleneck of emerging economies, which exerts negative impacts on agricultural export competitiveness in foreign markets. Overall, the interlink between globalisation, logistics and food supply has not been addressed adequately. Therefore, this paper employs the trade gravity model to examine the relationship between agricultural exports, RTAs membership, and logistics performance in the case of Vietnam and her 97 major trading partners. Static and dynamic panel data estimation are employed with the methods applied to solving the zero trade and endogeneity concerns. Findings confirm the interlink between globalisation, logistics and food supply. RTAs-based globalisation and logistics policies are intertwined to secure and diversify import-driven food supply. The unified framework for long-term and sustainable development which aims at strengthening the interlink between globalisation, logistics, agriculture and global food supply should be considered in policy formulation.
\end{abstract}

Keywords: Food supply, globalisation, trade gravity model, logistics performance, regional trade agreements (RTAs)

JEL classification: F14, F15, F69

\section{Introduction}

During the past two decades, economic globalisation has taken place extremely strongly, which has been reflected by the increasing number of regional trade agreements (RTAs). This contributes to creating a global market for products which includes agricultural products, thereby ensuring the continuity of global food supply. The relationship between globalisation, agricultural exports and the global food supply is more clearly recognised in the COVID-19 pandemic (Gruszczynski, 2020; Kerr, 2020; Kerr, 2021). As can be seen in Figure 1, with the rapid increase in the number of effective trade agreements, the world agricultural export has also increased.

a Faculty of Business Administration, Ton Duc Thang University, Ho Chi Minh City, Vietnam. Email: leducnha@tdtu.edu.vn, leducnha.nelah@gmail.com

ORCID: https://orcid.org/0000-0002-7601-2046

* There is no conflict of interests relevant to this paper.

Article Info: Received 19 March 2021; Revised 20 August 2021; Accepted 13 September 2021 https://doi.org/10.22452/MJES.vol58no2.5 


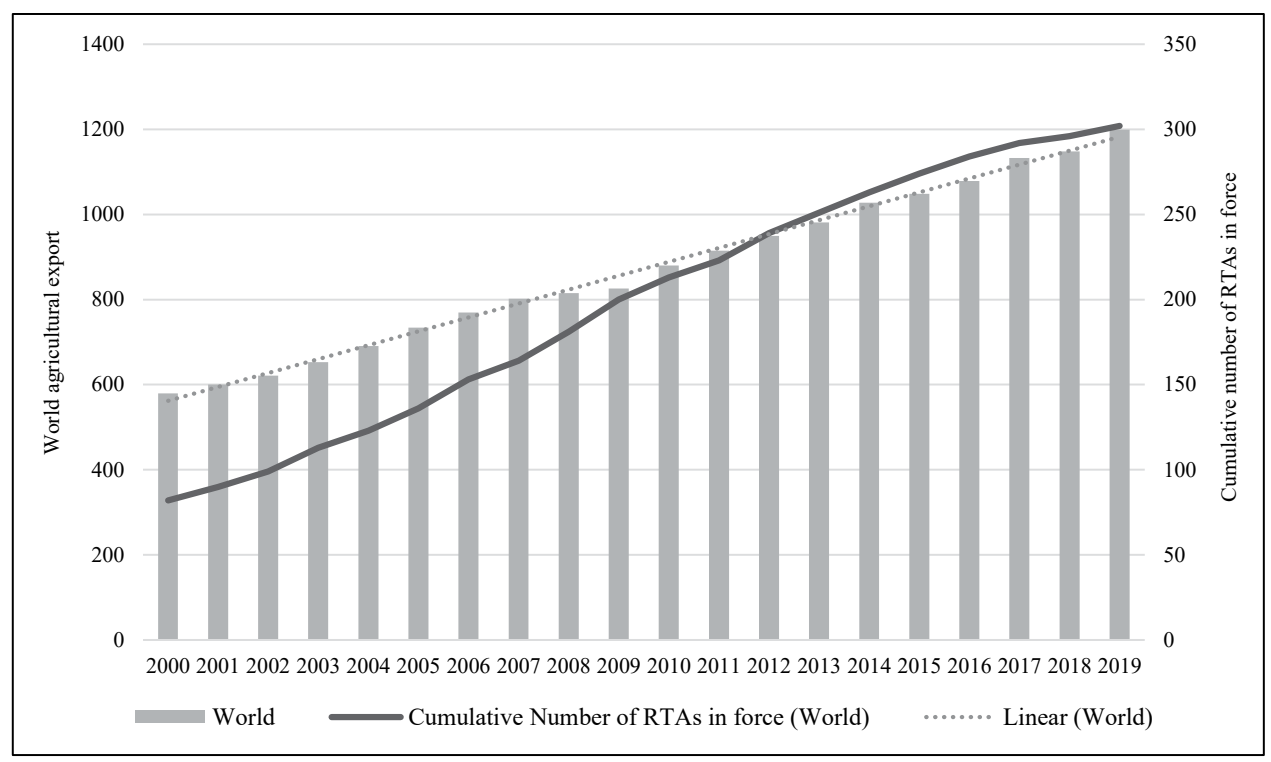

Figure 1: Cumulative number of regional trade agreements (RTAs) in force and world agricultural export, 2000-2019 (US\$ billion)

Source: FAO \& WTO, 2021.

This correlation partly demonstrates the role of globalisation, which is reflected in the increasing number of effective trade agreements on the stability of global food supplies in which agricultural export has a significant proportion. An effective trade agreement means tariff and non-tariff barriers to trade are removed and facilitated. In addition, a RTA theoretically allows protectionist policies to be phased out, which have been chronically used to protect the population in areas which are vulnerable to global competition such as agriculture. It is a positive sign of intention of members in facilitating greater market access, thus accelerating globalisation. Especially in the case of economies in East Asia and ASEAN, globalisation may be driven by the need of regional trading blocs in establishing trade ties with western partners (Park, 2020). In this case, globalisation is not based on the WTO-led multilateral trading system, instead it is driven by the emergence of global RTAs, especially those in East Asia (Chen, 2018; Chen \& Lombaerde, 2019).

Subject to relevant literature, globalisation includes two aspects, namely globalisation of markets and globalisation of production (Hill \& Hult, 2019, p. 6). From the perspective of globalisation of markets, both individual and institutional consumers' tastes and preferences of food and agricultural products tend to be convergent due to the fact many agricultural products serve essential needs and could be used as raw materials for food processing industries (Anderson et al., 2018; Hill \& Hult, 2019, p. 6). Therefore, globalisation creates the global market for agricultural products, thereby helping maintain global food supplies (Elleby et al., 2020; MacDonald et al., 2015; Qiang et al., 2020). From the perspective of globalisation of production, the global 
operational activities of multinationals have been expanding in many regions of the world (Hill \& Hult, 2019, p. 8; UNCTAD, 2020). Intra-firm trade activities have made up a large proportion of the global trade value (Huang et al., 2020; Lavoratori et al., 2020; Morikawa, 2019; Vinod \& Rao, 2019). Intra-firm exports arguably contributed approximately one-third of the world exports (UNCTAD, 2016). The international production chain of multinational enterprises has been expanding exponentially as value added to product of foreign affiliates is US\$8.0 trillion in 2019 (UNCTAD, 2020). This also contributes to agricultural exports increase and ensuring the stability of the global food supply (Bureau \& Swinnen, 2018; Enyinda \& Mbah, 2017; Smith \& Glauber, 2020). According to the World Bank, exports of agriculture, forestry and fishing is US\$3.68 trillion in 2020, which is 3.26 times greater than the export value in 2000 . In addition, two major drivers of economic globalisation are market liberalisation through the removal of trade and investment barriers, and technological advancements influencing the global food supply (Dithmer \& Abdulai, 2017; Hosoe, 2016; Sunge \& Ngepah, 2020). Specifically, trade agreements are the legal bases and commitments of governments to ensure the smooth flow of global trade in general and agricultural products in particular (Arita et al., 2017; Friel et al., 2020; Hofmann et al., 2019; Jagdambe \& Kannan, 2020). Meanwhile, logistics-related technology could reduce the cost of exported products and improve the operational performance, which enhances their competitiveness in foreign markets, thus facilitating greater globalisation (Gani, 2017; Lyu et al., 2019).

Vietnam is a developing country which is characterised by large trade openness, pro-globalisation economic agenda, dynamic integration process and having a significant proportion of the agricultural sector in the economic structure for a long time. The agricultural export of Vietnam plays an important role in maintaining the global food supply (Bandumula, 2018).

Figure 2 shows that in less than two decades Vietnam's agricultural export value has increased by 3.5 times with a turnover of US\$5.02 billion in 2000 and US\$17.55 billion in 2019, while world agricultural export only increased by 2.07 times in the 2000-2019 period. In addition, Vietnam's share in world agricultural export has increased from $0.87 \%$ in 2000 to $1.46 \%$ in 2019 . Over the past two decades of the 21st century, the proportion of Vietnam's share to the world agricultural export has been approximately $1.24 \%$ on average. Importing markets of Vietnamese agricultural products are very diverse and global. According to Vietnam's General Department of Customs, in the first two quarters of 2020, Vietnam's agricultural products have been mainly exported to countries such as China, Japan, Korea, the United States, Canada, Australia, New Zealand, and other countries in the European Union (EU), Taiwan, African countries such as Ghana, Senegal, Mozambique, Cameroon, Gabon, Tanzania and Egypt, as well as Southeast Asian countries such as Malaysia, Indonesia, Thailand and the Philippines.

Logistics performance has been identified as an engine of Vietnam's export growth (Banomyong et al., 2015; Lu \& Lin, 2012; Tang \& Abosedra, 2019). However, according to the Ministry of Industry and Trade (Vietnam) (2020), the logistics costs-to-GDP ratio of Vietnam is $16.8 \%$ in 2018 , while it is $10.7 \%$ at the global level, $12.7 \%$ in the Asia-Pacific region, $14.5 \%$ in China, $8.5 \%$ in Singapore, $15.0 \%$ in Thailand, and $13.0 \%$ 


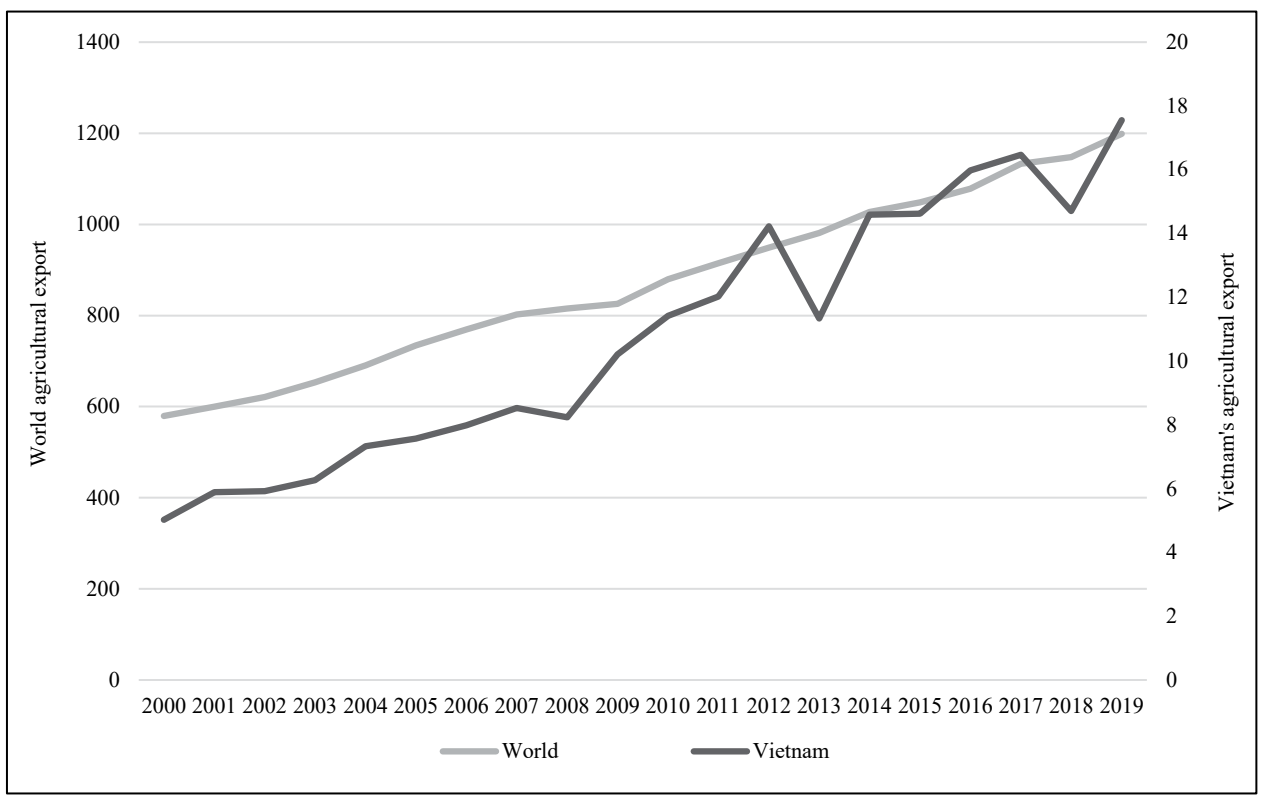

Figure 2: Agricultural export of the world and Vietnam, 2000-2019 (US\$ billion) Source: FAO \& WTO, 2021.

in Malaysia. In addition, the total logistics cost over sales of Vietnamese enterprises is 9.37\%. Thus, instead of enabling export, logistics performance has been the bottleneck of Vietnam's export competitiveness. Logistics performance is inversely proportional to the logistics cost of the exported goods, especially for perishable products of agriculture. Logistics performance of Vietnam has been facing challenges of interregional connectivity, physical and digital infrastructure, human resources, competitive logistics service market, legal transparency, and customs clearance-related fees and procedures (Banomyong, 2013; Banomyong et al., 2015; Lu \& Lin, 2012; Tongzon \& Lee, 2016). Given the nature of agricultural products, they are significantly affected by the national logistics performance. In the context of the COVID-19 pandemic, Vietnam's Ministry of Industry and Trade issued an official document No. 709/BCT-XNK in February 2020 to the Vietnam Logistics Business Association (VLA) which recommends the reduction of service costs for suppliers and businesses of agricultural products. ${ }^{1}$

Given these facts and statistics, whether RTA-based globalisation and logistics improve global food supply is questionable, which could be addressed by investigating the effects of RTAs participation and logistics performance on agricultural exports in the context of an export-oriented and agriculture-driven economy. This paper would provide solid evidence for the linkage between RTA-based globalisation, logistics performance and global food security. In addition, the findings are expected to

1 Ministry of Industry and Trade (Vietnam) (2020). https://moit.gov.vn/tin-tuc/thi-truong-nuoc-ngoai/cucxuat-nhap-khau-hop-voi-cac-hiep-hoi-nganh-hang-doanh-ngh.html, accessed on August 9th 2021. 
provide guidance for policymakers on shaping policies in the international integration, agricultural exports and logistics areas, which further strengthens the global food supply. For these reasons, this paper employs the logistics-augmented trade gravity model to examine the relationship between agricultural exports, trade agreements and logistics performance in the case of Vietnam. The remaining part of the paper comprised five sections. Section 2 summarises recent studies related to the trade gravity model, logistics and agricultural products. Section 3 establishes a research model to test the causal relationship between the phenomena in consideration. Section 4 discusses the data and methodology applied to the proposed model. Analytical results and discussion are presented in Section 5. Section 6 concludes the paper with policy implications and future directions for relevant research.

\section{Literature Review}

\subsection{What is Trade Gravity Model?}

The trade gravity model is inspired by the physical phenomenon of gravity between two objects in space. Accordingly, the gravitational force between two objects (gravity) will be proportional to the mass of each object and inversely proportional to the distance between the two objects. This idea was first applied to economics by Pöyhönen (1963) and Tinbergen (1962), which suggests bilateral trade between two countries is proportional to the size of each economy and inversely proportional to the geographical distance between the two countries. Later, many scholars have extended the traditional model by incorporating various macro-economic determinants of bilateral trade which consequently turns it to the augmented trade gravity model. Empirical results have justified and consolidated the augmented trade gravity model in diverse economies and industries. The model has been employed by many scholars in quantitative research on international trade (Kabir et al., 2017; Tham \& Kam, 2014).

The relevant literature has identified a list of macro-determinants of bilateral trade, which allow the inclusion of national characteristics in the estimation. With respect to economic growth, Tham and Kam (2014) argued that it is more appropriate to use the GDP per capita than GDP as it is well-proxied for the purchasing power of consumers and the prosperity of the economy. Other determinants are bilateral exchange rate fluctuations (Kahouli \& Omri, 2017; Narayan \& Nguyen, 2016), landlockedness (Kahouli \& Omri, 2017; Leng et al., 2020), and logistics performance and capacity (Gani, 2017; Martí et al., 2014; Martí \& Puertas, 2017). In addition, recent studies of Kahouli and Maktouf (2015), Kahouli (2016), Kahouli and Omri (2017), and Tham et al. (2018) have indicated the impact of exporter-importer income difference and economic similarity on bilateral trade. This impact could be positive or negative dependent on the nature of the trading relationship. To measure the effect of globalisation on export growth, a number of recent studies have employed a dummy variable which considers whether the exporting and importing country share common membership to a RTA in a certain year (Darmanto et al., 2021; Han \& Tian, 2020; Handoyo et al., 2021; Jagdambe \& Kannan, 2020). Most of these studies have focused on the case of ASEAN countries. 


\subsection{Logistics and International Trade}

In terms of national logistics performance, research prior to the advent of the Logistics Performance Index (LPI) has included a global logistics index which reflects the time, cost, complexity and risks of logistics-related activities (Hausman, 2004; Hausman et al., 2013; Lee \& Whang, 2005). Aspects of the global logistics index are also calculated using survey data but not on a 5-point scale as the LPI and its component indicators. Therefore, research which uses augmented trade gravity model with LPI-related variables are nascent. Some relevant research has been conducted by Bugarčić et al. (2020), Çelebi (2019), Gani (2017), Martí and Puertas (2017), Martí et al. (2014), Puertas et al. (2014) and Riadh (2020). These studies use national-level data of aggregate export revenue and none of these are conducted in the case of Vietnam. Therefore, this paper aims at employing the sectoral logistics-augmented trade gravity model with the incorporation of a set of proxies for trade agreements to examine the relationship between globalisation, logistics and food supply in the case of an emerging economy.

\section{Research Model}

Based on the trade gravity model, this paper employs the following estimation for examining the linkage between agricultural export, RTAs participation and logistics performance:

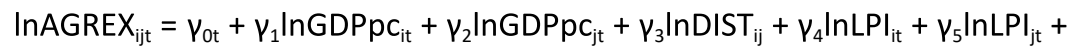

$$
\begin{aligned}
& \gamma_{6} \mathrm{RTA}_{\mathrm{ijt}}+\gamma_{7} \operatorname{InD} \_\mathrm{GDPpc}_{\mathrm{ijt}}+\gamma_{8} \operatorname{lnSIML_{ij\mathrm {t}}}+\gamma_{9} \operatorname{lnEXG_{jit}}+\gamma_{10} \mathrm{LAND}_{\mathrm{j}}+ \\
& \gamma_{11} \mathrm{BORD}_{\mathrm{ij}}+\varphi_{\mathrm{ijt}}
\end{aligned}
$$

where In indicates the natural logarithm, $i$ is the exporting country (Vietnam), $j$ is importing countries - the partners $(j=1, \ldots 97), t$ is the year of observation $(t=2007$, 2010, 2012, 2014, 2016 and 2018), $\nu_{o t}$ is the y-intercept which reflects cross-country variations in the estimation, the parameters from $v_{1}$ to $v_{11}$ indicate the associations between dependent and independent variables, and $\varphi_{i j t}$, is the error term of the estimation. The variables $I n L P I_{i t}$ and $I n L P I_{j t}$ represent the national logistics performance, while the $R T A_{i j t}$ is comprised of constituent proxies for specific effective regional trade agreements which have been signed by Vietnam and ASEAN. Table 1 provides the details of all variables in Model (1).

\section{Data and Methodology}

\subsection{Data Description}

This paper uses sectoral-level data for Vietnam and 97 trading partners for 2007, 2010, 2012, 2014, 2016 and 2018. Selected partners are major importing markets of Vietnam in the 2007-2018 period based on the data availability of agricultural export revenue and logistics performance index. With respect to the definition of agricultural products in international trade, Campi and Dueñas (2016) have recommended a detailed list of 
Table 1. Variables and measurement

\begin{tabular}{|c|c|c|}
\hline Variables & Measurement & Sources \\
\hline AGREX $_{\text {ijt }}$ & $\begin{array}{l}\text { Annual agricultural export of Vietnam (i) to country } j \\
\text { in year } t \text { (US\$ thousand). }\end{array}$ & World Bank \\
\hline $\mathrm{GDPpc}_{\mathrm{it}}$ & $\begin{array}{l}\text { Gross domestic product per capita of country } i \\
\text { (Vietnam) in year } t \text { (US\$ thousand/person). }\end{array}$ & World Bank \\
\hline $\mathrm{GDPpc}_{\mathrm{jt}}$ & $\begin{array}{l}\text { Gross domestic product per capita of country } j \\
\text { (importing countries) in year } t \text { (US\$ thousand/person). }\end{array}$ & World Bank \\
\hline DIST $_{i j}$ & $\begin{array}{l}\text { Geographical distance between Vietnam }(i) \text { and } \\
\text { country } j \text { (kilometres) }\end{array}$ & freemaptools.com \\
\hline D_GDPpc $c_{i j t}$ & $\begin{array}{l}\text { Difference in income per capita between country } \\
i \text { and } j \text { in year } t \text { (US\$ thousand/person): } \\
D_{-} \text {GDPpc }_{\mathrm{ijt}}=\left|\mathrm{GDPpc}_{\mathrm{it}}-\mathrm{GDPpc}_{\mathrm{jt}}\right|\end{array}$ & $\begin{array}{l}\text { As proposed by Kahouli } \\
\text { and Maktouf (2015), } \\
\text { Kahouli (2016), Kahouli } \\
\text { and Omri (2017), Tham et } \\
\text { al. (2018) }\end{array}$ \\
\hline $\mathrm{SIML}_{\mathrm{ijt}}$ & 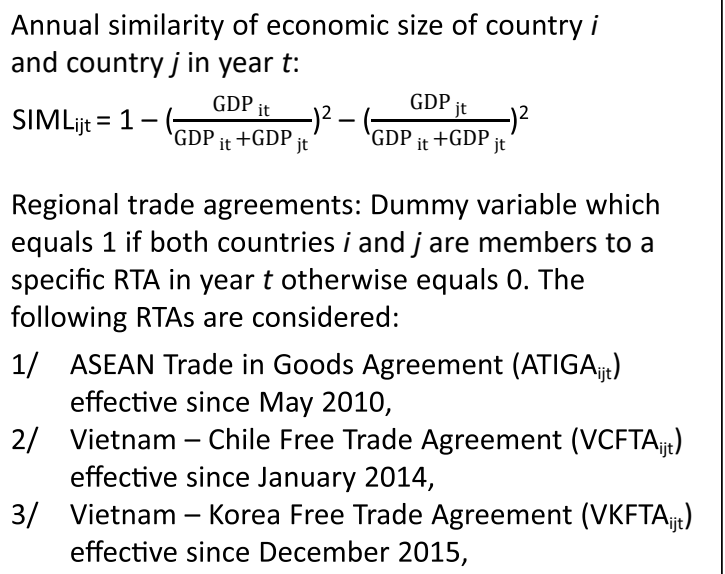 & $\begin{array}{l}\text { As proposed by Kahouli } \\
\text { and Maktouf (2015), } \\
\text { Kahouli (2016), Kahouli } \\
\text { and Omri (2017) }\end{array}$ \\
\hline $\begin{array}{l}\text { RTA }_{\text {ijt }} \text { and } \\
\text { specific } \\
\text { dummy } \\
\text { variables for } \\
\text { globalisation }\end{array}$ & 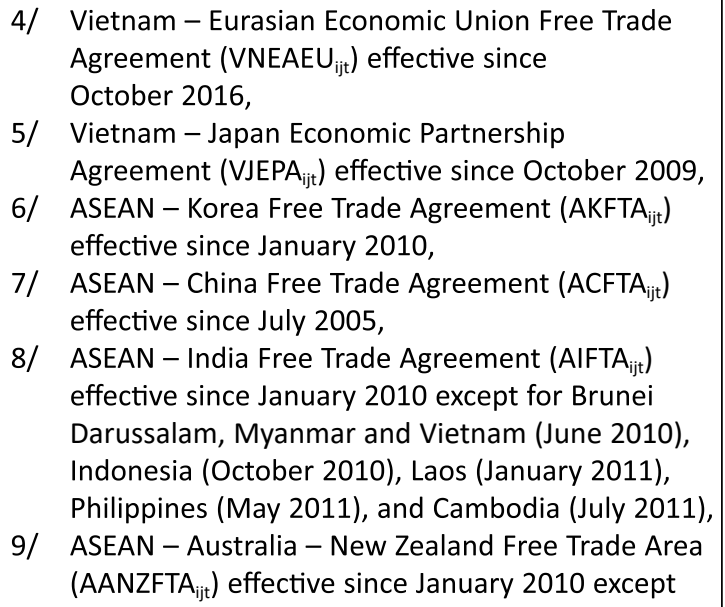 & WTO \\
\hline
\end{tabular}


Table 1. Continued

\begin{tabular}{|c|c|c|}
\hline Variables & Measurement & Sources \\
\hline & $\begin{array}{l}\text { for Thailand (March 2010), Laos and Cambodia } \\
\text { (January 2011), and Indonesia (January 2012), } \\
\text { 10/ ASEAN-Japan Comprehensive Economic } \\
\text { Partnership (AJCEP }{ }_{\text {ijt }} \text { ) effective since December } \\
2008 \text { except for Brunei Darussalam (January } \\
\text { 2009), Malaysia (February 2009), Thailand (June } \\
\text { 2009), Cambodia (December 2009), Indonesia } \\
\text { (March 2010), and Philippines (July 2010). }\end{array}$ & \\
\hline $\mathrm{EXG}_{\mathrm{jit}}$ & $\begin{array}{l}\text { Annual bilateral exchange rate (Local currency unit of } \\
\text { country } i \text { per local currency unit of country } j \text { ) in year } t \text {. }\end{array}$ & $\begin{array}{l}\text { UNCTAD, as proposed by } \\
\text { Kahouli and Maktouf } \\
\text { (2015), Kahouli (2016), } \\
\text { Kahouli and Omri (2017). }\end{array}$ \\
\hline LAND $_{j}$ & $\begin{array}{l}\text { Landlockedness: Dummy variable which equals } 1 \text { if } \\
\text { country } j \text { is landlocked otherwise equals } 0 .\end{array}$ & Google Map \\
\hline $\mathrm{BORD}_{\mathrm{ij}}$ & $\begin{array}{l}\text { Common border: Dummy variable which equals } 1 \text { if } \\
\text { country } i \text { and } j \text { share a common land border } \\
\text { otherwise equals } 0 \text {. }\end{array}$ & Google Map \\
\hline $\mathrm{LPI}_{i t}$ & $\begin{array}{l}\text { Annual overall logistics performance index of } \\
\text { country } i \text { in year } t \text {. }\end{array}$ & World Bank \\
\hline $\mathrm{LPI}_{\mathrm{jt}}$ & $\begin{array}{l}\text { Annual overall logistics performance index of } \\
\text { country } j \text { in year } t \text {. }\end{array}$ & World Bank \\
\hline
\end{tabular}

merchandise with Harmonised System (HS) code for the data collection by empirical studies on international trade. Accordingly, agricultural products are those with HS codes from chapters 1-24, except for chapters 3, 16 and some types in chapters 29-53. Thus, agricultural products in this paper do not include seafood products.

Data sources are macro-economic statistical databases of global institutions which are the World Bank, World Trade Organization (WTO) and United Nations Conference on Trade and Development (UNCTAD). The biennial LPI is collected and calculated for the first time in 2007 by the World Bank. Survey questionnaires are distributed to worldwide respondents whose answers are used as input for LPI calculation. The 5-point scale is applied to measure LPI and its component indicators, where 1 indicates the lowest performance and 5 indicates the highest performance. The component indicators of LPI are: (i) Efficiency of customs and border management clearance (CUS); (ii) Quality of transport and trade infrastructure (INF); (iii) Ease of arranging competitively priced shipments (SHIP); (iv) Competence and quality of logistics services-trucking, forwarding, and customs brokerage (LGS); (v) Ability to track and trace consignments (TNT); and (vi) Frequency with which shipments reach consignees within scheduled or expected delivery times (TLN). 


\subsection{Preliminary Analysis}

Prior to the regression, panel unit-root and panel cointegration tests are deployed. Due to the applicability of the panel unit-root tests and the availability of data, for the variables with strongly balanced data (no missing values), the Levin-Lin-Chu unit-root test and the Harris-Tzavalis unit-root test are applicable, while for those with unbalanced data $\left(A_{G R E X_{i j t}}\right.$ ), the Fisher-type unit-root test would be employed. In the research model, the variable $A G R E X_{i j t}$ is 0 in certain cases when there is no agricultural trade between Vietnam and a trading partner in the specific year(s). In those cases, the logarithm of trade is undefined, which causes the missing values and consequently the unbalanced data. The null hypothesis of those tests indicates the existence of unit roots in the panels.

Panel cointegration tests are performed to examine the stable long-term relationship of the relevant variables as employed by Roy and Chatterjee (2013), and Stack and Pentecost (2011). The tests of Kao (MDFt, DFt, ADFt, UmDFt, and UDFt) (Kao, 1999), Pedroni (MPPt, PPt, ADFt) (Pedroni, 1999), and Westerlund (variance ratio) (Westerlund, 2005) are employed, whose null hypothesis indicates there is no cointegration among included variables. Thus, the number of component panel cointegration tests is 9 . The stable long-term relationship is confirmed when findings reject the null hypotheses of at least 5 out of 9 component panel cointegration tests. The value of included variables is considered in the original form. Data is processed and refined by using Excel software before estimation using STATA software version 15.1.

\subsection{Baseline Analysis}

Following Kahouli (2016), Kahouli and Maktouf (2015), Leng et al. (2020), and Tham et al. (2018), this paper uses the fixed effect (FE) and random effect (RE) estimation for static panel data. According to Kabir et al. (2017), fixed effect estimation allows the intercepts to vary by individuals, which is appropriate for considering national characteristics in the panel data. In addition, time dummies could be included in the fixed effect model to examine changes due to temporal facilitators and inhibitors. Meanwhile, the random effect model allows the time-invariant independent variables to be included in the estimation of the gravity model. This is useful as the trade gravity model has a number of nation-specific variables which are stable and almost unchanged in the long term. The Hausman tests are applied to determine whether fixed effect or random effect estimation is more appropriate for the research model.

\subsection{Robustness to the Zero Trade Issue}

Following Jagdambe and Kannan (2020), Khurana and Nauriyal (2017), and Shahriar et al. (2019), this paper uses the pooled OLS (POLS), Poisson pseudo maximum likelihood (PPML), and Heckman sample selection (HSS) estimation to solve the zero trade issue. In this paper, the estimation by POLS and PPML methods is employed with the original value of agricultural exports to avoid the undefined logarithm of zero value of trade. As could be seen in Table 2, the minimum value of agricultural exports in the data set is 0 , which implies that zero trade is a possible problem in the estimation. Meanwhile, the HSS estimation uses the dummy variable Integration $_{i j t}$, which equals 1 if country $i$ 
Table 2. Descriptive statistics

\begin{tabular}{lcccrr}
\hline Variables & Observation & Mean & Standard Deviation & Minimum & Maximum \\
\hline AGREX $_{\text {ijt }}$ & 582 & 129625.1 & 413504.6 & 0 & 5723625 \\
GDPpc $_{\text {it }}$ & 582 & 1.799412 & .5439145 & .9192092 & 2.551123 \\
GDPpc $_{\text {jt }}$ & 582 & 18.89546 & 22.6391 & .3588275 & 119.1727 \\
DIST $_{\text {ij }}$ & 582 & 9187.276 & 4586.205 & 392.848 & 19387.52 \\
LPI $_{\text {it }}$ & 582 & 3.043221 & .1290911 & 2.888855 & 3.27 \\
LPI $_{\text {jt }}$ & 582 & 3.048401 & .6156895 & 1.862039 & 4.225967 \\
D_GDPpc $_{\text {ijt }}$ & 582 & 17.49475 & 22.31541 & .0018706 & 117.1204 \\
SIML $_{\text {ijt }}$ & 582 & .3018976 & .1543329 & .0105809 & .499996 \\
EXG $_{\text {jit }}$ & 582 & 8669.946 & 10571.57 & 1.587564 & 34798.35 \\
\hline
\end{tabular}

Notes: AGREX $\mathrm{ijt}_{\mathrm{jt}}$ is the agricultural export revenue (US\$ thousand) from country $i$ (Vietnam) to country $j$ (Vietnam's trading partners) in year $t$ (where $t=2007,2010,2012,2014,2016,2018$ ). GDPpc it is the per capita gross domestic product of country $i$ in year $t$ (US\$ thousand/person). GDPpc $c_{j t}$ is the per capita gross domestic product of country $j$ in year $t$ (US\$ thousand/person). DIST $T_{i j}$ is the geographic distance from country $i$ to country $j$ (kilometres). $\mathrm{LP}_{\mathrm{it}}$ and $\mathrm{LP}_{\mathrm{jt}}$ are the logistics performance index of country $i$ and $j$ in year $t$. D_GDPpc ijt is the difference in per capita GDP of country $i$ and $j$ in year $t$ (US\$ thousand/person). SIML $\mathrm{L}_{\mathrm{jit}}$ is the economic similarity between GDP of country $i$ and $j$ in year $t$. EXG $_{\mathrm{jit}}$ is the annual bilateral exchange rate (local currency unit of country $i$ per local currency unit of country $j$ ) in year $t$.

and $j$ are the parties to at least one RTA in year $t$ and 0 otherwise, to be the selection basis because members to RTAs are the most likely to have bilateral trade. Thus, HSS estimation is employed to exclude the zero trade values in the panel data.

\subsection{Robustness to Endogeneity}

Following Kahouli (2016), Kahouli and Maktouf (2015), and Tham et al. (2018), this paper uses the first-differenced and system generalised method of moments (D-GMM and S-GMM) methods for dynamic panel data, which could tackle the endogeneity. Tham et al. (2018) have argued that GMM estimation includes time-invariant variables in the trade gravity model, which could complement the fixed effect model. In addition, this paper uses D-GMM and S-GMM models with one-step (I) and two-step (II) options. Kahouli and Maktouf (2015) indicated that the D-GMM method uses lagged values of variables in the estimation which could mitigate the endogeneity issue in the model, while the S-GMM method is the most useful estimation for persistent short panel data of export flows (Kahouli, 2016). In order to determine the appropriate models, this paper employs the overidentification and autocorrelation tests, whose p-values are expected to be higher than 0.05 to validate the models. To examine the overidentification of the instruments, the paper employs the Sargan test for onestep estimations and the Hansen test for two-step estimations whose null hypothesis indicates valid instruments. In addition, to inspect the autocorrelation in the models, the Arellano-Bond test for ar2 is employed, whose null hypothesis indicates the nonexistence of the autocorrelation of second order. The instrumental variables are the RTAs dummy variables as employed by Kahouli (2016). 


\section{Empirical Results}

\subsection{Summary Statistics}

Table 2 indicates the descriptive statistics of included variables. A total number of 582 observations are employed for model estimation. The minimum value of $A G R E X_{i j t}$ is 0 , which reveals the necessity of dealing with the zero trade issue in the estimation. The mean value of $L P I_{i t}$ is approximately 3.04, which suggests that logistics performance of Vietnam is not competitive because the mean value of LPI is 2.50. Pearson's correlation coefficients in Table 3 indicate that the variable InAGREX $X_{i j t}$ is correlated with all variables in the model at the significance level of $1 \%$. In addition, some explanatory variables are significantly correlated to others, which implies the likelihood of multicollinearity concern in the POLS estimation.

Table 3. Pearson correlation tests

\begin{tabular}{|c|c|c|c|c|c|c|c|c|c|}
\hline & $\ln A G R E X_{i j t}$ & $\operatorname{lnGDPpc_{it}}$ & $\operatorname{lnGDPpc}_{\mathrm{jt}}$ & $\operatorname{lnDIST}_{\mathrm{ij}} \ln$ & $\mathrm{D}_{-} \mathrm{GDPpc}_{\mathrm{ijt}}$ & $\operatorname{lnSIML} L_{\mathrm{ijt}}$ & $\ln E X G_{j i t}$ & $\left.\operatorname{lnLPI}\right|_{i t}$ & $\left.\ln L P\right|_{j t}$ \\
\hline InAGREX & 1.0000 & & & & & & & & \\
\hline $\operatorname{lnGDPpc_{it}}$ & $0.1814^{* * *}$ & 1.0000 & & & & & & & \\
\hline $\operatorname{lnGDPpc_{\mathrm {jt}}}$ & $0.1707^{* * *}$ & $0.0752^{*}$ & 1.0000 & & & & & & \\
\hline $\ln \mathrm{DIST}_{\mathrm{ij}}$ & $-0.4046^{* * *}$ & -0.0000 & 0.0681 & 1.0000 & & & & & \\
\hline InD_GDPpc $c_{i j t}$ & $0.1101^{* * *}$ & $0.0743^{*}$ & $0.8923^{* * *}$ & $0.1478^{* * *}$ & 1.0000 & & & & \\
\hline $\operatorname{lnSIML} L_{\mathrm{ijt}}$ & $-0.1431^{* * *}$ & 0.0328 & $0.3062^{* * *}$ & $-0.1062^{* *}$ & $0.0984^{* *}$ & 1.0000 & & & \\
\hline $\ln \mathrm{EXG}_{\mathrm{jit}}$ & $0.1410^{* * *}$ & -0.0003 & $0.7256^{* * *}$ & $0.1395^{* * *}$ & $0.6191^{* * *}$ & $0.3267^{* * *}$ & 1.0000 & & \\
\hline$\left.\ln L P\right|_{i t}$ & $0.1491^{* * *}$ & $0.7965^{* * *}$ & $0.0701^{*}$ & -0.0000 & 0.0669 & 0.0276 & -0.0011 & 1.0000 & \\
\hline$\left.\operatorname{lnLP|}\right|_{j t}$ & $0.3667^{* * *}$ & $0.0794^{*}$ & $0.8673^{* * *}$ & $-0.0971^{* *}$ & $0.7473^{* * *}$ & $0.2527^{* * *}$ & $0.6883^{* * *}$ & 0.0464 & 1.000 \\
\hline
\end{tabular}

Notes: $L n$ is the natural logarithm. AGREX $\mathrm{ijt}_{\mathrm{t}}$ is the agricultural export revenue (US\$ thousand) from country $i$ (Vietnam) to country $j$ (Vietnam's trading partners) in year $t$ (where $t=2007,2010,2012,2014$, 2016,2018 ). GDPpc it is the per capita gross domestic product of country $i$ in year $t$ (US\$ thousand/ person). $\mathrm{GDPpc}_{\mathrm{jt}}$ is the per capita gross domestic product of country $j$ in year $t$ (US\$ thousand/ person). DIST ${ }_{i j}$ is the geographic distance from country $i$ to country $j$ (kilometres). LPI $_{i t}$ and LPI $_{j t}$ are the logistics performance index of country $i$ and $j$ in year $t$. D_GDPpc $c_{\text {ijt }}$ is the difference in per capita GDP of country $i$ and $j$ in year $t$ (US\$ thousand/person). SIML $\mathrm{Lijt}_{\mathrm{ijt}}$ is the economic similarity between GDP of country $i$ and $j$ in year $t$. EXG $\mathrm{G}_{\mathrm{jit}}$ is the annual bilateral exchange rate (local currency unit of country $i$ per local currency unit of country $j$ ) in year $t .{ }^{* * *},{ }^{* *},{ }^{*}$ indicate statistical significance at the $1 \%, 5 \%$ and $10 \%$ levels, respectively.

\subsection{Preliminary Analysis ${ }^{2}$}

The panel unit-root tests indicate that all variables are stationary because the $p$-values are less than 0.05 which reject the null hypothesis of the existence of unit roots in the panels. In terms of panel cointegration, the stable long-term relationships between agricultural exports, logistics performance and RTAs participation are confirmed by the Kao (MDFt, DFt, ADFt, UmDFt, UDFt), Pedroni (MPPt, PPt, ADFt), and Westerlund (variance ratio) (including and excluding time trends) tests. In terms

2 To conserve space, the results for panel unit-root tests and panel cointegration tests are not tabulated but available upon request from the authors. 
of agricultural exports and logistics performance, all component tests confirm their long-term relationship, except the Westerlund test of the importing country's logistics performance (variance ratio $=1.2522$ ). In terms of agricultural exports and difference in income per capita, all component tests confirm their long-term relationship, except the Westerlund test (variance ratio $=-0.2609$ ). In terms of agricultural exports and economic similarity, all of the component tests appear to confirm their long-term relationship, except the Westerlund test (variance ratio $=0.6837$ ) and the unavailable Pedroni test. In terms of agricultural exports and bilateral exchange rate, all component tests confirm their long-term relationship, except the Westerlund test (variance ratio = -1.2053). In terms of agricultural exports and RTAs dummy variables, the Pedroni tests' results are not available. Meanwhile, the case of ACFTA is inconclusive as there are only 3 out of 9 component tests reported. A majority of the component panel cointegration tests indicate the long-term relationship between agricultural exports and the other RTAs dummy variables. Overall, findings of the panel cointegration tests indicate that RTAs-based globalisation, logistics performance and imports-driven food supply have a stable relationship in the long term due to the rejected null hypotheses of the majority of component tests.

\subsection{Baseline Analysis}

The results of the baseline model are presented in Table 4. The baseline model includes Columns (1), (2) and (3) for importer-fixed effect, year-fixed effect, and random effect estimation respectively. The results of Hausman tests demonstrate that the models in Columns (1) and (2) are more appropriate than the model in Column (3). The results of $\mathrm{F}$ tests indicate that the fixed effect estimation is more appropriate than the POLS

Table 4. Baseline results

\begin{tabular}{lccc}
\hline & $(1)$ & $(2)$ & $(3)$ \\
& $\mathrm{FE}$ & $\mathrm{FE}^{\prime}$ & $\mathrm{RE}$ \\
& InAGREX $_{\mathrm{ijt}}$ & InAGREX $_{\mathrm{ijt}}$ & InAGREX $_{\mathrm{ijt}}$ \\
\hline InGDPpc $_{\mathrm{it}}$ & $0.822^{* * *}$ & $0.868^{* * *}$ & $0.904^{* * *}$ \\
& $(0.000)$ & $(0.000)$ & $(0.000)$ \\
$\operatorname{lnGDPpc}_{\mathrm{jt}}$ & $0.710^{* * *}$ & $0.648^{* * *}$ & $0.313^{* *}$ \\
& $(0.003)$ & $(0.006)$ & $(0.041)$ \\
$\operatorname{lnDIST}_{\mathrm{ij}}$ & & & $-0.997^{* * *}$ \\
& & & $(0.002)$ \\
$\operatorname{lnLPI}_{\mathrm{it}}$ & -1.375 & -1.735 & -0.534 \\
& $(0.267)$ & $(0.202)$ & $(0.670)$ \\
$\operatorname{lnLPI}_{\mathrm{jt}}$ & 0.574 & 0.434 & $1.181^{* *}$ \\
& $(0.345)$ & $(0.477)$ & $(0.046)$ \\
ATIGA $_{\mathrm{ijt}}$ & 0.791 & 0.848 & 0.543 \\
& $(0.522)$ & $(0.491)$ & $(0.655)$ \\
VCFTA $_{\mathrm{ijt}}$ & 0.239 & 0.278 & 0.237 \\
VKFTA $_{\mathrm{ijt}}$ & $(0.678)$ & $(0.628)$ & $(0.684)$ \\
& 0.092 & 0.266 & 0.202 \\
& $(0.885)$ & $(0.680)$ & $(0.759)$ \\
\hline
\end{tabular}


Table 4. Continued

\begin{tabular}{|c|c|c|c|}
\hline & $\begin{array}{c}(1) \\
F E \\
\text { InAGREX }{ }_{i j t}\end{array}$ & $\begin{array}{c}(2) \\
\mathrm{FE}^{\prime} \\
\text { InAGREX }\end{array}$ & $\begin{array}{c}(3) \\
\text { RE } \\
\text { InAGREX }\end{array}$ \\
\hline VNEAEU $_{\mathrm{ijt}}$ & $\begin{array}{l}-0.686 \\
(0.134)\end{array}$ & $\begin{array}{l}-0.646 \\
(0.159)\end{array}$ & $\begin{array}{l}-0.796 * \\
(0.086)\end{array}$ \\
\hline VJEPA $_{i j t}$ & $\begin{array}{c}0.694 \\
(0.567)\end{array}$ & $\begin{array}{c}0.634 \\
(0.600)\end{array}$ & $\begin{array}{l}1.333 \\
(0.263)\end{array}$ \\
\hline AKFTA $_{i j t}$ & $\begin{array}{c}0.390 \\
(0.632)\end{array}$ & $\begin{array}{c}0.244 \\
(0.765)\end{array}$ & $\begin{array}{l}0.665 \\
(0.396)\end{array}$ \\
\hline ACFTA $_{i j t}$ & & & $\begin{array}{c}0.282 \\
(0.760)\end{array}$ \\
\hline AIFTA $_{i j t}$ & $\begin{array}{c}0.196 \\
(0.708)\end{array}$ & $\begin{array}{c}0.230 \\
(0.660)\end{array}$ & $\begin{array}{c}0.323 \\
(0.521)\end{array}$ \\
\hline AANZFTA $_{i j t}$ & $\begin{array}{l}-0.233 \\
(0.620)\end{array}$ & $\begin{array}{l}-0.221 \\
(0.637)\end{array}$ & $\begin{array}{l}-0.164 \\
(0.713)\end{array}$ \\
\hline $\mathrm{AJCEP}_{\mathrm{ijt}}$ & $\begin{array}{l}-0.865 \\
(0.354)\end{array}$ & $\begin{array}{l}-0.830 \\
(0.373)\end{array}$ & $\begin{array}{l}-0.944 \\
(0.315)\end{array}$ \\
\hline InD_GDPpc $c_{\mathrm{ijt}}$ & $\begin{array}{l}-0.022 \\
(0.728)\end{array}$ & $\begin{array}{l}-0.026 \\
(0.688)\end{array}$ & $\begin{array}{l}-0.079 \\
(0.216)\end{array}$ \\
\hline $\operatorname{lnSIML} L_{\mathrm{ijt}}$ & $\begin{array}{c}0.382^{*} \\
(0.053)\end{array}$ & $\begin{array}{c}0.380^{*} \\
(0.054)\end{array}$ & $\begin{array}{l}-0.140 \\
(0.353)\end{array}$ \\
\hline $\ln E X G_{j i t}$ & $\begin{array}{c}0.088 \\
(0.624)\end{array}$ & $\begin{array}{l}-0.065 \\
(0.735)\end{array}$ & $\begin{array}{c}0.034 \\
(0.620)\end{array}$ \\
\hline $\operatorname{LAND}_{j}$ & & & $\begin{array}{l}-2.855^{* * *} \\
(0.000)\end{array}$ \\
\hline $\mathrm{BORD}_{\mathrm{ij}}$ & & & $\begin{array}{l}1.052 \\
(0.355)\end{array}$ \\
\hline Constant & $\begin{array}{l}8.844^{* * *} \\
(0.000)\end{array}$ & $\begin{array}{l}10.481^{* * *} \\
(0.000)\end{array}$ & $\begin{array}{l}16.796^{* * *} \\
(0.000)\end{array}$ \\
\hline Observations & 563 & 563 & 563 \\
\hline Number of IMPORTER1 & 97 & 97 & 97 \\
\hline Year-fixed effect & No & Yes & - \\
\hline $\begin{array}{l}\mathrm{F} \text { test } \\
\text { Hausman test (chi2) }\end{array}$ & $\begin{array}{l}32.76^{* * *} \\
45.20^{* * *}\end{array}$ & $\begin{array}{l}32.96^{* * *} \\
67.83^{* * *}\end{array}$ & $\begin{array}{l}- \\
-\end{array}$ \\
\hline
\end{tabular}

Notes: $L n$ is the natural logarithm. The results of $F$ test indicate that fixed effect estimation is more appropriate than the POLS estimation. The results of Hausman tests indicate that fixed effect estimation is more appropriate than random effect estimation. AGREX $\mathrm{ijt}_{\mathrm{it}}$ is the agricultural export revenue (US\$ thousand) from country $i$ (Vietnam) to country $j$ (Vietnam's trading partners) in year $t$ (where $t=2007,2010,2012,2014,2016,2018)$. GDPpc it is the per capita gross domestic product of country $i$ in year $t$ (US\$ thousand/person). GDPpc is $_{\text {it }}$ the per capita gross domestic product of country $j$ in year $t$ (US\$ thousand/person). DIST $\mathrm{ij}_{\mathrm{ij}}$ is the geographic distance from country $i$ to country $j$ (kilometres). $\mathrm{LPI}_{\mathrm{it}}$ and $\mathrm{LPI}_{\mathrm{jt}}$ are the logistics performance index of country $i$ and $j$ in year $t$. D_GDPpc $\mathrm{c}_{\mathrm{ijt}}$ is the difference in per capita GDP of country $i$ and $j$ in year $t$ (US\$ thousand/person). SIML $L_{\mathrm{ijt}}$ is the economic similarity between GDP of country $i$ and $j$ in year $t$. EXG $\mathrm{Git}_{\mathrm{jit}}$ is the annual bilateral exchange rate (local currency unit of country $i$ per local currency unit of country $j$ ) in year $t$. Omitted variables are determined based on the dependency with the remaining independent variables in the model. P-values are presented in brackets. ${ }^{* *}, * *, *$ indicate statistical significance at the $1 \%, 5 \%$ and $10 \%$ levels, respectively. 
estimation. Findings of Column (1) and (2) confirm the positive relationship between agricultural exports and economic growth. In terms of logistics performance, findings of Columns (1) and (2) do not confirm its impact on agricultural exports. In terms of RTAs-based globalisation, findings of Columns (1) and (2) do not confirm the link between RTAs membership and agricultural exports, which is similar to findings of relevant research of Kahouli (2016), Kahouli and Maktouf (2015), and Khurana and Nauriyal (2017). This implies that RTA-based globalisation may not facilitate agricultural trade between members, which does not contribute to the secure food supply. In addition, globalisation may go beyond signing RTAs and require more comprehensive and radical improvements in the agriculture of the exporting country. However, RTAs are the prerequisite for globalisation and secure global food supply. In terms of the other determinants, economic similarity has a positive impact on agricultural exports in Columns (1) and (2). This implies that agricultural trade between partners of similar economic size could be tightened more effectively.

\subsection{Robustness to the Zero Trade Issue}

Robustness to the zero trade issue is presented in Table 5, which includes Columns (4), (5) and (6) for POLS, PPML and HSS estimations respectively. As can be seen in Table 5, Column (4) indicates the multicollinearity with the VIF value greater than 10 in some variables while the mean VIF is 9.52. Therefore, the model in Column (4) is not appropriate for the estimation. In addition, the chi2_c value is valid at the significance level of $10 \%$, thus the model in Column (6) could be used to consider the relationship between the variables. Findings of Columns (5) and (6) confirm the positive link between agricultural exports and economic growth. Nevertheless, Column (6) only confirms the positive impact of exporting country's economic growth on agricultural

Table 5. Robustness to the zero trade issue

\begin{tabular}{|c|c|c|c|}
\hline & $\begin{array}{c}(4) \\
\text { POLS } \\
\text { AGREX }_{\text {ijt }}\end{array}$ & $\begin{array}{c}(5) \\
\text { PPML } \\
\text { AGREX }_{\text {ijt }}\end{array}$ & $\begin{array}{c}\text { (6) } \\
\text { HSS } \\
\text { InAGREX }\end{array}$ \\
\hline $\operatorname{lnGDPpc_{it}}$ & $\begin{array}{c}190,495.4^{* * *} \\
(0.002)\end{array}$ & $\begin{array}{c}1.590 * * * \\
(0.000)\end{array}$ & $\begin{array}{c}0.862^{* * * *} \\
(0.008)\end{array}$ \\
\hline $\ln G D P p c_{j t}$ & $\begin{array}{c}47,792.3^{*} \\
(0.095)\end{array}$ & $\begin{array}{c}0.262 * * \\
(0.042)\end{array}$ & $\begin{array}{c}0.187 \\
(0.224)\end{array}$ \\
\hline $\operatorname{lnDIST} T_{i j}$ & $\begin{array}{c}58,722.0^{* *} \\
(0.039)\end{array}$ & $\begin{array}{c}-0.390 * * * \\
(0.000)\end{array}$ & $\begin{array}{c}-0.913^{* * *} \\
(0.000)\end{array}$ \\
\hline$\left.\operatorname{lnLPI}\right|_{i t}$ & $\begin{array}{c}-73,189.1 \\
(0.883)\end{array}$ & $\begin{array}{l}-0.518 \\
(0.647)\end{array}$ & $\begin{array}{c}0.953 \\
(0.721)\end{array}$ \\
\hline$\left.\ln L P\right|_{j t}$ & $\begin{array}{c}447,019.5^{* * *} \\
(0.001)\end{array}$ & $\begin{array}{c}4.440 * * * \\
(0.000)\end{array}$ & $\begin{array}{c}5.024^{* * *} \\
(0.000)\end{array}$ \\
\hline $\mathrm{ATIGA}_{\mathrm{ijt}}$ & $\begin{array}{c}-178,692.5 \\
(0.635)\end{array}$ & $\begin{array}{c}0.363 \\
(0.391)\end{array}$ & $\begin{array}{c}0.366 \\
(0.858)\end{array}$ \\
\hline VCFTA $_{i j t}$ & $\begin{array}{c}-24,074.8 \\
(0.893)\end{array}$ & $\begin{array}{c}-0.674 * * * \\
(0.001)\end{array}$ & $\begin{array}{c}0.474 \\
(0.627)\end{array}$ \\
\hline
\end{tabular}


Table 5. Continued

\begin{tabular}{|c|c|c|c|}
\hline & $\begin{array}{c}(4) \\
\text { POLS } \\
\text { AGREX }_{\mathrm{ijt}}\end{array}$ & $\begin{array}{c}(5) \\
\text { PPML } \\
\text { AGREX }_{\mathrm{ijt}}\end{array}$ & $\begin{array}{c}\text { (6) } \\
\text { HSS } \\
\text { InAGREX }\end{array}$ \\
\hline VKFTA & $\begin{array}{c}110,957.9 \\
(0.686)\end{array}$ & $\begin{array}{l}0.089 \\
(0.584)\end{array}$ & $\begin{array}{c}0.347 \\
(0.817)\end{array}$ \\
\hline VNEAEU $_{\mathrm{ijt}}$ & $\begin{array}{c}76,049.4 \\
(0.667)\end{array}$ & $\begin{array}{l}0.876 \\
(0.232)\end{array}$ & $\begin{array}{l}-0.060 \\
(0.949)\end{array}$ \\
\hline VJEPA $_{i j t}$ & $\begin{array}{c}1,077,602.3^{* * *} \\
(0.003)\end{array}$ & $\begin{array}{c}0.538 \\
(0.130)\end{array}$ & $\begin{array}{l}1.394 \\
(0.476)\end{array}$ \\
\hline AKFTA $_{\mathrm{ijt}}$ & $\begin{array}{c}204,950.6 \\
(0.261)\end{array}$ & $\begin{array}{c}0.628 * * * \\
(0.004)\end{array}$ & $\begin{array}{c}0.773 \\
(0.436)\end{array}$ \\
\hline ACFTA $_{\text {ijt }}$ & $\begin{array}{l}1,171,712.3^{* * *} \\
(0.000)\end{array}$ & $\begin{array}{c}1.808^{* * *} \\
(0.000)\end{array}$ & $\begin{array}{c}0.770 \\
(0.186)\end{array}$ \\
\hline AIFTA $_{\mathrm{ijt}}$ & $\begin{array}{c}76,676.5 \\
(0.522)\end{array}$ & $\begin{array}{c}-0.746 * * * \\
(0.009)\end{array}$ & $\begin{array}{l}-0.530 \\
(0.414)\end{array}$ \\
\hline AANZFTA $_{i j t}$ & $\begin{array}{c}-16,503.6 \\
(0.855)\end{array}$ & $\begin{array}{l}0.010 \\
(0.948)\end{array}$ & $\begin{array}{c}0.358 \\
(0.465)\end{array}$ \\
\hline AJCEP $_{\mathrm{ijt}}$ & $\begin{array}{c}-964,116.1^{* * *} \\
(0.003)\end{array}$ & $\begin{array}{c}-0.901^{* *} \\
(0.013)\end{array}$ & $\begin{array}{l}-1.200 \\
(0.502)\end{array}$ \\
\hline $\operatorname{lnD}{ }_{-} \mathrm{GDPpc}_{\mathrm{ijt}}$ & $\begin{array}{c}-48,899.1 * * * \\
(0.005)\end{array}$ & $\begin{array}{c}-0.404 * * * \\
(0.000)\end{array}$ & $\begin{array}{c}-0.384 * * * \\
(0.000)\end{array}$ \\
\hline $\operatorname{lnSIML} L_{\mathrm{ijt}}$ & $\begin{array}{c}-167,191.2^{* * *} \\
(0.000)\end{array}$ & $\begin{array}{c}-0.987^{* * *} \\
(0.000)\end{array}$ & $\begin{array}{c}-0.794 * * * \\
(0.000)\end{array}$ \\
\hline $\ln E X G_{j i t}$ & $\begin{array}{l}14,572.0^{* *} \\
(0.032)\end{array}$ & $\begin{array}{l}0.017 \\
(0.517)\end{array}$ & $\begin{array}{l}0.033 \\
(0.375)\end{array}$ \\
\hline $\mathrm{LAND}_{\mathrm{j}}$ & $\begin{array}{c}-100,393.9 * * \\
(0.017)\end{array}$ & $\begin{array}{c}-2.248 * * * \\
(0.000)\end{array}$ & $\begin{array}{c}-2.209 * * * \\
(0.000)\end{array}$ \\
\hline $\mathrm{BORD}_{\mathrm{ij}}$ & $\begin{array}{c}428,638.5^{* * *} \\
(0.000)\end{array}$ & $\begin{array}{c}-0.899 * * * \\
(0.003)\end{array}$ & $\begin{array}{l}-0.435 \\
(0.432)\end{array}$ \\
\hline Constant & $\begin{array}{c}-1,310,565.5^{* *} \\
(0.034)\end{array}$ & $\begin{array}{c}7.769 * * * \\
(0.000)\end{array}$ & $\begin{array}{c}10.186^{* * *} \\
(0.002)\end{array}$ \\
\hline Observations & 582 & 582 & 563 \\
\hline $\begin{array}{l}\text { Number of IMPORTER1 } \\
\text { chi2_c }\end{array}$ & $\begin{array}{l}- \\
-\end{array}$ & $\begin{array}{l}- \\
-\end{array}$ & $3 . \overline{24} *$ \\
\hline $\begin{array}{l}\text { Mean VIF } \\
\text { VIF }>10\end{array}$ & 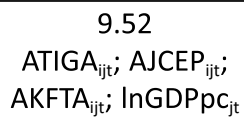 & & \\
\hline
\end{tabular}

Notes: $L n$ is the natural logarithm. Chi2_c is the statistics of LR tests for independent equations $\left(\mathrm{H}_{0}:\right.$ rho $=$ 0 ). AGREX $\mathrm{ijt}_{\mathrm{ijt}}$ is the agricultural export revenue (US\$ thousand) from country $i$ (Vietnam) to country $j$ (Vietnam's trading partners) in year $t$ (where $t=2007,2010,2012,2014,2016,2018)$. GDPpc $_{i t}$ is the per capita gross domestic product of country $i$ in year $t$ (US\$ thousand/person). GDPpc $c_{j t}$ is the per capita gross domestic product of country $j$ in year $t$ (US\$ thousand/person). DIST $\mathrm{ij}_{\mathrm{j}}$ is the geographic distance from country $i$ to country $j$ (kilometres). $L P I_{i t}$ and $L^{2} I_{j t}$ are the logistics performance index of country $i$ and $j$ in year $t$. D_GDPpc ijt $_{\text {in }}$ is the difference in per capita GDP of country $i$ and $j$ in year $t$ (US\$ thousand/person). SIML ${ }_{i j t}$ is the economic similarity between GDP of country $i$ and $j$ in year $t$. $\operatorname{EXG}_{\mathrm{jit}}$ is the annual bilateral exchange rate (local currency unit of country $i$ per local currency unit of country $j$ ) in year $t$. P-values are presented in brackets. ${ }^{* * *}, * *, *$ indicate statistical significance at the $1 \%, 5 \%$ and $10 \%$ levels, respectively. 
exports, while the link between importing country's economic growth and agricultural exports is not significant.

In addition, findings of Columns (5) and (6) indicate the negative link between geographic distance and agricultural exports. Meanwhile, the importing country's logistics performance appears to boost agricultural exports in Columns (5) and (6). In terms of RTAs-based globalisation, findings of Column (6) do not support the link between RTAs participation and agricultural exports, thereby the globalisation-food supply linkage is not confirmed. Nevertheless, relevant findings of Column (5) are twofold. On one hand, the VCFTA, AIFTA and AJCEP appear to be negatively associated with agricultural exports, and the three attached coefficients has a total value of -2.321 . In the case of the VCFTA, it could be explained that Vietnam's exporting enterprises could not take the advantages related to agricultural exports from this trade agreement with Chile. Similarly, that logic applies to the case of AIFTA and AJCEP as those are signed by India, Japan and ASEAN whose members include Vietnam. Therefore, food supply may be imported from the other ASEAN countries by Indian and Japanese importers, which results in the decrease of Vietnam's agricultural exports. In addition, the negative impact of RTAs membership in this paper is similar to relevant research of Gharleghi and Shafighi (2020), Jagdambe and Kannan (2020), Lohani (2020), and Narayan and Nguyen (2016). Moreover, Kahouli (2016) has argued that the trade creation effect of RTAs, which is proxied by the dummy variables of RTAs membership, is unstable and unpredictable. In these studies, it has been indicated that the negative coefficients of some RTA dummy variables may arguably imply the implementation of certain RTAs could unintentionally lead to the trade diversion effect (export and import diversion) which is not considered in this paper. This paper has examined the trade creation effect among members to a specific RTA. In addition, in the case of East Asia and the Pacific region, RTAs are established which do not aim at creating trade among members, instead it may be either the reaction to the creation of other RTAs in the EU and North America or the reflection of the fear of being left behind in the integration process. On the other hand, the AKFTA and ACFTA are positively associated with agricultural exports with the total value of coefficients of 2.436. Consequently, the net value of five significant RTAs dummy variables' coefficients is 0.115 . Therefore, the globalisationfood supply linkage is confirmed in Column (5).

In terms of difference in income per capita, findings of Columns (5) and (6) indicate its negative impact on agricultural exports. This may reveal the greater magnitude of agricultural trade between partners of similar income levels. This could be explained that income levels determine the sophistication of consumer demand, which considerably influences the agriculture-related non-tariff barriers. Thus, partners of similar income levels would require equivalent and mutually-recognised agricultural production and distribution standards, which reduces time and costs relevant to technical compliance of exported products, which ultimately increases the agricultural trade. In terms of economic similarity, findings of Columns (5) and (6) indicate its negative impact on agricultural exports. This is contrary to the results of Columns (1) and (2) of the baseline model. Therefore, the effect of economic similarity varies by estimation methods. In terms of geographic disadvantage, landlockedness of the importing country is the barrier to agricultural exports in Columns (5) and (6). Thus, 
logistics performance could help expand national food supply by imports despite geographic disadvantages. Overall, findings of Columns (5) and (6) demonstrate the positive link between RTAs-based globalisation, logistics performance, and importdriven food supply. In terms of contiguity, findings of Column (5) indicates its negative impact on agricultural exports. This could be explained that nearby countries share common climatic and natural conditions, which results in the similarity in agricultural products. Furthermore, from the specific situation of Vietnam, much effort has been invested to reduce the undue dependence on the nearby agricultural consumption market of China, which may lead to the decrease in agricultural trade with contiguous countries.

\subsection{Robustness to Endogeneity}

Robustness to the endogeneity is presented in Table 6, which includes Columns (7), (8), (9) and (10) for D-GMM one-step (D-GMM(I)), D-GMM two-step (D-GMM(II)), S-GMM one-step (S-GMM(I)), and S-GMM two-step (S-GMM(II)) estimation respectively. In which, for two-step estimations, the p-values of Arellano-Bond (ar2) and Hansen (hansen) tests are greater than 0.05 would confirm its validity. Meanwhile, the ArellanoBond (ar2) and Sargan test (sargan) whose p-values are greater than 0.05 would justify one-step models. More importantly, RTAs dummy variables are used as instrumental variables in the estimation models. Findings reveal that only Column (10) is valid for the panel data. Most strikingly, findings of Column (10) indicates a negative relationship between agricultural exports and the exporting country's economic growth. Meanwhile, the impact of importing country's economic growth on agricultural exports is positive and insignificant. Therefore, the effect of economic growth on agricultural exports appears to vary by estimation methods.

In terms of geographic distance, findings of Column (10) demonstrates its negative impact on agricultural exports. Noticeably, the logistics performance of exporting and importing country is positively and significantly associated with agricultural exports. This implies that the import-driven food supply could be secured by logistics performance. In other words, the positive link between logistics and food supply is confirmed by the findings of Column (10). In terms of RTAs-based globalisation, findings unveil the positive impact of the VNEAEU on agricultural exports. However, the AIFTA is negatively and significantly associated with agricultural exports, which is similar to the findings of Column (5). This could be concluded that the impact of RTAs participation on agricultural exports vary by trading partners. Overall, the net value of significant coefficients relevant to RTAs-based globalisation and logistics performance in Column (10) is 4.854 . Thus, the combined effect of RTAs-based globalisation and logistics performance on import-driven food supply appears to be significantly positive. In terms of difference in income per capita, findings of Column (10) confirm its negative impact on agricultural exports, which is similar to the findings of Column (5) and (6). Meanwhile, the impact of economic similarity on agricultural exports appears to vary by estimation methods. Specifically, the positive link is confirmed by the findings of Columns (1) and (2), whereas the negative link is confirmed by the findings of Columns (5), (6), and (10). 
Table 6. Robustness to endogeneity

\begin{tabular}{|c|c|c|c|c|}
\hline & $\begin{array}{c}(7) \\
\text { D-GMM(I) } \\
\text { InAGREX }\end{array}$ & $\begin{array}{c}(8) \\
\text { D-GMM(II) } \\
\text { InAGREX }\end{array}$ & $\begin{array}{c}(9) \\
\text { S-GMM(I) } \\
\text { InAGREX }\end{array}$ & $\begin{array}{c}(10) \\
\text { S-GMM(II) } \\
\text { InAGREX } \\
\text { ijt }\end{array}$ \\
\hline L.InAGREX $\mathrm{ijt}_{\mathrm{jt}}$ & $\begin{array}{c}0.133 \\
(0.140)\end{array}$ & $\begin{array}{l}0.149 * * * \\
(0.000)\end{array}$ & $\begin{array}{l}0.708^{* * *} \\
(0.000)\end{array}$ & $\begin{array}{l}0.698 * * * \\
(0.000)\end{array}$ \\
\hline L.InGDPpc $c_{i t}$ & $\begin{array}{c}0.192 \\
(0.390)\end{array}$ & $\begin{array}{l}0.379 * * * \\
(0.006)\end{array}$ & $\begin{array}{l}-0.426^{* *} \\
(0.011)\end{array}$ & $\begin{array}{l}-0.369 * * \\
(0.035)\end{array}$ \\
\hline L.InGDPpc $c_{j t}$ & $\begin{array}{l}-0.161 \\
(0.688)\end{array}$ & $\begin{array}{l}-0.240 \\
(0.404)\end{array}$ & $\begin{array}{c}0.033 \\
(0.866)\end{array}$ & $\begin{array}{c}0.071 \\
(0.742)\end{array}$ \\
\hline $\operatorname{InDIST}_{\mathrm{ij}}$ & & & $\begin{array}{l}-0.728^{* *} \\
(0.016)\end{array}$ & $\begin{array}{l}-0.581^{*} \\
(0.078)\end{array}$ \\
\hline$\left.\ln L P\right|_{i t}$ & $\begin{array}{c}1.522 \\
(0.127)\end{array}$ & $\begin{array}{l}1.712^{* * *} \\
(0.000)\end{array}$ & $\begin{array}{c}1.942 * \\
(0.078)\end{array}$ & $\begin{array}{l}2.063 * * \\
(0.042)\end{array}$ \\
\hline$\left.\operatorname{lnLP|}\right|_{j t}$ & $\begin{array}{l}1.535 \\
(0.284)\end{array}$ & $\begin{array}{l}1.846^{* * *} \\
(0.000)\end{array}$ & $\begin{array}{c}2.781^{* *} \\
(0.030)\end{array}$ & $\begin{array}{l}3.039 * * \\
(0.018)\end{array}$ \\
\hline $\mathrm{ATIGA}_{\mathrm{ijt}}$ & & & $\begin{array}{l}-1.946 \\
(0.282)\end{array}$ & $\begin{array}{l}-1.092 \\
(0.795)\end{array}$ \\
\hline VCFTA $_{i j t}$ & $\begin{array}{l}-0.049 \\
(0.948)\end{array}$ & $\begin{array}{c}0.002 \\
(0.986)\end{array}$ & $\begin{array}{c}0.665^{* *} \\
(0.028)\end{array}$ & $\begin{array}{c}0.494 \\
(0.140)\end{array}$ \\
\hline VKFTA $_{\text {ijt }}$ & $\begin{array}{c}0.099 \\
(0.892)\end{array}$ & $\begin{array}{c}0.000 \\
(1.000)\end{array}$ & $\begin{array}{c}0.408 \\
(0.184)\end{array}$ & $\begin{array}{c}0.636 \\
(0.582)\end{array}$ \\
\hline VNEAEU $_{\mathrm{ijt}}$ & $\begin{array}{c}0.381 \\
(0.453)\end{array}$ & $\begin{array}{c}0.251^{*} \\
(0.056)\end{array}$ & $\begin{array}{l}0.550^{* *} \\
(0.016)\end{array}$ & $\begin{array}{l}0.550^{* *} \\
(0.029)\end{array}$ \\
\hline VJEPA $_{i j t}$ & & & $\begin{array}{l}-1.431^{*} \\
(0.077)\end{array}$ & $\begin{array}{l}-0.555 \\
(0.812)\end{array}$ \\
\hline AKFTA $_{i j t}$ & & & $\begin{array}{l}-0.281 \\
(0.657)\end{array}$ & $\begin{array}{l}-0.455 \\
(0.778)\end{array}$ \\
\hline ACFTA $_{i j t}$ & & & $\begin{array}{c}2.153 \\
(0.255)\end{array}$ & $\begin{array}{c}2.251 \\
(0.310)\end{array}$ \\
\hline AlFTA $_{\mathrm{ijt}}$ & $\begin{array}{l}-0.047 \\
(0.919)\end{array}$ & $\begin{array}{l}-0.741 * * * \\
(0.000)\end{array}$ & $\begin{array}{l}-0.876^{* *} \\
(0.016)\end{array}$ & $\begin{array}{l}-0.798^{*} \\
(0.098)\end{array}$ \\
\hline AANZFTA $_{i j t}$ & & $\begin{array}{l}0.822^{* * *} \\
(0.000)\end{array}$ & $\begin{array}{c}0.134 \\
(0.529)\end{array}$ & $\begin{array}{l}-0.000 \\
(0.999)\end{array}$ \\
\hline AJCEP $P_{i j t}$ & $\begin{array}{l}-0.690 \\
(0.442)\end{array}$ & & $\begin{array}{c}0.734 \\
(0.154)\end{array}$ & $\begin{array}{l}-0.059 \\
(0.976)\end{array}$ \\
\hline L.InD_GDPpc $c_{\mathrm{ijt}}$ & $\begin{array}{l}-0.114 \\
(0.255)\end{array}$ & $\begin{array}{l}-0.159 * * * \\
(0.003)\end{array}$ & $\begin{array}{l}-0.235^{* *} \\
(0.013)\end{array}$ & $\begin{array}{l}-0.269 * * \\
(0.021)\end{array}$ \\
\hline L.InSIML & $\begin{array}{c}0.156 \\
(0.597)\end{array}$ & $\begin{array}{l}-0.018 \\
(0.926)\end{array}$ & $\begin{array}{l}-0.435^{* * *} \\
(0.009)\end{array}$ & $\begin{array}{l}-0.455^{* * *} \\
(0.009)\end{array}$ \\
\hline L.InEXG $\mathrm{jit}_{\mathrm{jt}}$ & $\begin{array}{l}0.783^{* *} \\
(0.012)\end{array}$ & $\begin{array}{l}0.785^{* * *} \\
(0.000)\end{array}$ & $\begin{array}{c}0.037 \\
(0.630)\end{array}$ & $\begin{array}{c}0.016 \\
(0.860)\end{array}$ \\
\hline LAND $_{\mathrm{j}}$ & & & $\begin{array}{l}-0.518 \\
(0.516)\end{array}$ & $\begin{array}{l}-0.584 \\
(0.542)\end{array}$ \\
\hline $\mathrm{BORD}_{\mathrm{ij}}$ & & & $\begin{array}{l}-2.891 \\
(0.161)\end{array}$ & $\begin{array}{l}-2.838 \\
(0.182)\end{array}$ \\
\hline Constant & - & - & $\begin{array}{c}4.104 \\
(0.186)\end{array}$ & $\begin{array}{c}2.539 \\
(0.467)\end{array}$ \\
\hline
\end{tabular}


Table 6. Continued

\begin{tabular}{|c|c|c|c|c|}
\hline & $\begin{array}{c}(7) \\
\text { D-GMM(I) } \\
\text { InAGREX }_{\text {ijt }}\end{array}$ & $\begin{array}{c}\text { (8) } \\
\text { D-GMM(II) } \\
\text { InAGREX }_{\text {ijt }}\end{array}$ & $\begin{array}{c}\text { (9) } \\
\text { S-GMM(I) } \\
\text { InAGREX }\end{array}$ & $\begin{array}{c}\text { (10) } \\
\text { S-GMM(II) } \\
\text { InAGREX }\end{array}$ \\
\hline Observations & 368 & 368 & 464 & 464 \\
\hline Number of IMPORTER1 & 95 & 95 & 96 & 96 \\
\hline Number of instruments & 50 & 50 & 75 & 75 \\
\hline $\operatorname{ar} 2 p$ & 0.00323 & 0.0282 & 0.0701 & 0.0701 \\
\hline ar2 & $2.945 * * *$ & $2.195 * *$ & $1.811^{*}$ & $1.811^{*}$ \\
\hline ar1p & $1.15 \mathrm{e}-06$ & 0.0650 & 0.0115 & 0.0220 \\
\hline ar1 & $-4.864 * * *$ & $-1.845^{*}$ & $-2.527^{* *}$ & $-2.290 * *$ \\
\hline sarganp & 0.0585 & 0.0585 & 0.0210 & 0.0210 \\
\hline sargan & $41.80^{*}$ & $41.80^{*}$ & $75.96 * *$ & $75.96 * *$ \\
\hline hansenp & & 0.143 & 0.160 & 0.160 \\
\hline hansen & & 37.11 & 63.16 & 63.16 \\
\hline IVs & All RTAs o & variables & & \\
\hline
\end{tabular}

Notes: $L n$ is the natural logarithm. For relevant tests, ar1, ar2, sargan, and hansen are Arellano-Bond tests for the autocorrelation existence of first order, Arellano-Bond tests for the autocorrelation existence of second order, Sargan tests for over-identification of one-step estimations, and Hansen tests for over-identification of two-step estimations, respectively. The $p$-values of those tests are $\operatorname{ar} 1 p$, $\operatorname{ar} 2 p$, sarganp, and hansenp, respectively. AGREX $\mathrm{ijt}_{\mathrm{it}}$ is the agricultural export revenue (US\$ thousand) from country $i$ (Vietnam) to country $j$ (Vietnam's trading partners) in year $t$ (where $t=2007,2010$, $2012,2014,2016,2018) . G D P p c_{\text {it }}$ is the per capita gross domestic product of country $i$ in year $t$ (US\$ thousand/person). GDPpc $\mathrm{j}_{\mathrm{jt}}$ is the per capita gross domestic product of country $j$ in year $t$ (US\$ thousand/person). DIST $i \mathrm{ij}$ is the geographic distance from country $i$ to country $j$ (kilometres). LPI $_{i t}$ and $\mathrm{LPI}_{\mathrm{jt}}$ are the logistics performance index of country $i$ and $j$ in year $t$. D_GDPpc $\mathrm{c}_{\mathrm{ijt}}$ is the difference in per capita GDP of country $i$ and $j$ in year $t$ (US\$ thousand/person). SIML iit $_{\text {it }}$ is the economic similarity between GDP of country $i$ and $j$ in year $t$. EXG jit $_{\text {it }}$ is the annual bilateral exchange rate (local currency unit of country $i$ per local currency unit of country $j$ ) in year $t$. P-values are presented in brackets. Omitted variables are determined based on the dependency with the remaining independent variables in the model. ${ }^{* *}, * *, *$ indicate statistical significance at the $1 \%, 5 \%$ and $10 \%$ levels, respectively.

\section{Conclusion}

Globalisation, logistics and food supply have been the concern of national governments for the sustainable development over the past decades. In the age of flourishing RTAs and logistics-related technological enhancements, food supply is secured by importing sources of foreign markets as trade and logistics-related costs have been reduced. In other words, the imports-driven food supply has become the focus of national food policies. Thus, agricultural exports are the priority in national policy agenda because it helps the exporting country take advantages of RTAs participation and allows the importing country to consolidate and diversify its food supply. Therefore, the paper has aimed at examining the relationship between globalisation, which is called RTAs-based globalisation - proxied by the participation in effective RTAs, logistics performance and food supply, which is proxied by agricultural exports and called imports-driven food supply. The gravity model is employed due to its applicability and generalisability in 
empirical trade studies. In addition, it enables the incorporation of a variety of macroeconomic determinants into the estimation to control the national characteristics in trading relationship. Vietnam is the country for data collection as this is a dynamic economy in the RTAs-based globalisation process with important contribution to world agricultural trade. Furthermore, Vietnam has shaped various policies on enhancing logistics performance to strengthen the agricultural export competitiveness over the past two decades in the 21st century. The fixed effect and random effect estimation have been applied to the baseline model. The zero trade and endogeneity issue are solved by various methods.

Findings vary by estimation methods and trading partners. Nevertheless, some implications could be discussed from the perspectives of the exporting and importing country. In terms of the relationship between agricultural exports and economic growth, the imports-driven food supply could be consolidated and diversified by the rapid economic growth of trading partners. Thanks to the RTAs-globalisation, governments should expand its trading relationship with economies of rapid and sustainable growth to obtain benefits from increased exporting revenue (for the exporting country), and secure and diverse food supply (for the importing country). From the corporate perspective, agricultural and food enterprises should establish business transactions with partners from countries of rapid and sustainable economic growth to boost sales growth (for the exporter) and allocate the risks relevant to sourcing volatility (for the importer). In terms of the relationship between agricultural exports and logistics performance, investment policies on logistics enhancements should be the priority to ensure the imports-driven food supply (for the importing country) and allow the more comprehensive participation in the global food supply chain (for the exporting country). Furthermore, logistics policies could help the importing country overcome its geographic disadvantages in agricultural trade, which mitigates the negative effect of those natural barriers on imports-driven food supply. In other words, the importing country could become less dependent on domestic food supply and a limited number of nearby foreign markets thanks to the logistics enhancements.

In terms of the relationship between agricultural exports and RTAs dummy variables, RTAs-globalisation does not immediately facilitate the agricultural trade and consolidate the food supply without effective long-term policies to sustainably capitalise on the RTAs' potential advantages. In some certain cases, the RTAs establishment may result in the decrease of agricultural export revenue of the exporting country, which prevents the participation in the global food supply. Thus, exporting countries need to simultaneously negotiate and sign a number of RTAs with all of their major trading partners to diversify foreign food markets. Similarly, importing countries should enter various RTAs with their major food supply markets. More importantly, the regional economic integration and logistics policies should be shaped and implemented in a simultaneous and consistent manner to improve agricultural trade and imports-driven food supply. In other words, RTAs-based globalisation and logistics performance enhancement are the important contributors to the sustainable food supply.

In terms of difference in income per capita, the negative link with agricultural exports indicate the greater trade potentials between countries of similar income levels. This implies that the shrinking gap of income levels between trading partners 
is the promising signal of a tightened trading relationship in agriculture and a greater interconnected food supply chain. In addition, developing food exporters could increase export revenues by entering the international trade with other emerging markets based on their agriculture-specific comparative advantages. In turn, developed countries could be able to diversify and consolidate their food supply thanks to the trading relationship with emerging suppliers with rapid economic growth. Furthermore, the negative impact of income gap on agricultural trade could be mitigated by reducing the gap in technical requirements or non-tariff trade barriers. In this case, the mutual recognition and technical assistance in agriculture could be implemented to enhance agricultural trade and food supply. In the light of this implication, members to a RTA should increase the number of mutually-recognised agriculture-related standards and enhance the effectiveness of agriculture-related technical cooperation in the negotiation and implementation stage of the RTA participation.

In terms of economic similarity, findings of different estimation methods are inconclusive and unstable. Nevertheless, the significant effect on agricultural exports is confirmed, which means the imports-driven food supply is influenced by the similarity in economic size of trading partners. In the age of RTAs-based globalisation with flourishing agreements, findings relevant to difference in income per capita and economic similarity imply that governments should design separate policies for separate markets dependent on their economic development, and their importance to the national economy in general and agricultural trade and food supply in particular. This could help more effectively capitalise on the benefits of RTAs participation. In robust models, economic similarity appears to be negatively associated with agricultural exports, which implies that countries of different economic sizes have more tightened agricultural trading relationship. This could be explained that the productivity gap has resulted in the international labour division, which facilitates the agricultural trade flows. Therefore, the analysis of national comparative advantages should be applied to the agricultural export policy formulation for a wide range of major agricultural commodities and food products. In other words, the mindset of major agricultural products for major markets should be embedded in the policy formulation and implementation. In terms of the stable long-term relationship between agricultural exports and each of the included explanatory variables, which include logistics performance, difference in income per capita, economic similarity, bilateral exchange rate, and RTA dummy variables, findings imply that governments should include those areas in a unified framework for long-term and sustainable development policies, which aim at strengthening the interlink between globalisation, logistics, agriculture, and global food supply.

In the future, a larger number of exporting countries should be considered for a wider applicability and better generalisability of the findings. Specifically, they should be the major agricultural and food exporters of the global food supply. Sub-sectoral data of specific agricultural and food products could be considered for separate policy implications. In addition to trade creation, trade diversion, which includes export and import diversion, should be included in the model to comprehensively assess the impact of RTAs-based globalisation on food supply. In particular, a set of three RTAs dummy variables, which are trade creation, export diversion, and import diversion, could be employed for the assessment. Component indicators of the Logistics Performance Index 
should be included in the estimation, which could lend detailed and specific support to various aspects of the national logistics policies. In other words, future research could employ logistics-augmented trade gravity model as a novel frame work for empirical trade studies. For a better control of national charateristics in the gravity model, a number of other macro-determinants should be included, especially those proxied for institutional environments of exporting and importing countries.

\section{References}

Anderson, J. L., Asche, F., \& Garlock, T. (2018). Globalization and commoditization: The transformation of the seafood market. Journal of Commodity Markets, 12, 2-8. https://doi. org/10.1016/j.jcomm.2017.12.004

Arita, S., Beckman, J., \& Mitchell, L. (2017). Reducing transatlantic barriers on US-EU agri-food trade: What are the possible gains? Food Policy, 68, 233-247. https://doi.org/10.1016/j. foodpol.2016.12.006

Bandumula, N. (2018). Rice production in Asia: Key to global food security. Proceedings of the National Academy of Sciences, India Section B: Biological Sciences, 88(4), 1323-1328. https:// doi.org/10.1007/s40011-017-0867-7

Banomyong, R. (2013). The greater Mekong sub-region of Southeast Asia: improving logistics connectivity. In J. Bookbinder (Ed.), Handbook of Global Logistics (pp. 69-96). Springer. https://doi.org/10.1007/978-1-4419-6132-7_4

Banomyong, R., Thai, V.V., \& Yuen, K.F. (2015). Assessing the national logistics system of Vietnam. The Asian Journal of Shipping and Logistics, 31(1), 21-58. https://doi.org/10.1016/j. ajsl.2015.03.002

Bugarčić, F. Ž., Skvarciany, V., \& Stanišić, N. (2020). Logistics performance index in international trade: Case of Central and Eastern European and Western Balkans countries. Business: Theory and Practice, 21(2), 452-459. https://doi.org/10.3846/btp.2020.12802

Bureau, J. C., \& Swinnen, J. (2018). EU policies and global food security. Global Food Security, 16, 106-115. https://doi.org/10.1016/j.gfs.2017.12.001

Campi, M., \& Dueñas, M. (2016). Intellectual property rights and international trade of agricultural products. World Development, 80, 1-18. https://doi.org/10.1016/j.worlddev. 2015.11.014

Çelebi, D. (2019). The role of logistics performance in promoting trade. Maritime Economics \& Logistics, 21(3), 307-323. https://doi.org/10.1057/s41278-017-0094-4

Chen, L. (2018). Japan and China in a two-hub formation of regional integration in East Asia. In H. Loewen \& A. Zorob (Eds.), Initiatives of regional integration in Asia in comparative perspective (pp. 23-41). Springer. https://doi.org/10.1007/978-94-024-1211-6_2

Chen, L., \& Lombaerde, P.D. (2019). ASEAN between globalization and regionalization. Asia Pacific Business Review, 25(5), 729-750. https://doi.org/10.1080/13602381.2019.1652982

Darmanto, E.B., Handoyo, R.D., \& Wibowo, W. (2021). The impact of ASEAN-China Free Trade Area (ACFTA) agreement on Indonesia's major plantation export commodities. Business: Theory and Practice, 22(1), 91-97. https://doi.org/10.3846/btp.2021.11012

Dithmer, J., \& Abdulai, A. (2017). Does trade openness contribute to food security? A dynamic panel analysis. Food Policy, 69, 218-230. https://doi.org/10.1016/j.foodpol.2017.04.008

Elleby, C., Domínguez, I.P., Adenauer, M., \& Genovese, G. (2020). Impacts of the COVID-19 pandemic on the global agricultural markets. Environmental and Resource Economics, 76(4), 1067-1079. https://doi.org/10.1007/s10640-020-00473-6

Enyinda, C. I., \& Mbah, C. H. (2017). Quantifying sources of risk in global food operations and supply chain. Thunderbird International Business Review, 59(6), 653-661. https://doi. org/10.1002/tie.21842 
Food and Agriculture Organization (FAO). (2021). FAOSTAT. https://www.fao.org/faostat/en/ \#rankings/countries_by_commodity_exports

Friel, S., Schram, A., \& Townsend, B. (2020). The nexus between international trade, food systems, malnutrition and climate change. Nature Food, 1(1), 51-58. https://doi.org/10.1038/s43016019-0014-0

Gani, A. (2017). The logistics performance effect in international trade. The Asian Journal of Shipping and Logistics, 33(4), 279-288. https://doi.org/10.1016/j.ajsl.2017.12.012

Gharleghi, B., \& Shafighi, N. (2020). Do regional trade agreements increase trade? Empirical evidence from the Asia-Pacific region. Economic Affairs, 40(3), 419-435. https://doi.org/ 10.1111/ecaf.12435

Gruszczynski, L. (2020). The COVID-19 pandemic and international trade: Temporary turbulence or paradigm shift? European Journal of Risk Regulation, 11(2), 337-342. https://doi. org/10.1017/err.2020.29

Han, J., \& Tian, Z. (2020). The effect of trade creation in China-ASEAN free trade area based on the gravity model. Journal of Intelligent \& Fuzzy Systems, 38(6), 7061-7065. https://doi. org/10.3233/JIFS-179784

Handoyo, R.D., Sugiharti, L., \& Esquivias, M. A. (2021). Trade creation and trade diversion effects: The case of the ASEAN Plus Six Free Trade Area. Buletin Ekonomi Moneter dan Perbankan, 24(1), 93-118. https://doi.org/10.21098/bemp.v24i1.1163

Hausman, W.H. (2004). Supply chain performance metrics. In T.P. Harrison, H.L. Lee, \& J.J. Neale (Eds.), The practice of supply chain management: Where theory and application converge (pp. 61-73). Springer. https://doi.org/10.1007/0-387-27275-5_4

Hausman, W.H., Lee, H.L., \& Subramanian, U. (2013). The impact of logistics performance on trade. Production and Operations Management, 22(2), 236-252. https://doi.org/10.1111/ j.1937-5956.2011.01312.x

Hill, C.W.L., \& Hult, G.T.M. (2019). International business: Competing in the global marketplace. McGraw-Hill Education.

Hofmann, C., Osnago, A., \& Ruta, M. (2019). The content of preferential trade agreements. World Trade Review, 18(3), 365-398. https://doi.org/10.1017/\$1474745618000071

Hosoe, N. (2016). The double dividend of agricultural trade liberalization: Consistency between national food security and gains from trade. Journal of Asian Economics, 43, 27-36. https:// doi.org/10.1016/j.asieco.2016.02.001

Huang, J., Krull, L., \& Ziedonis, R. (2020). R\&D investments and tax incentives: The role of intrafirm cross-border collaboration. Contemporary Accounting Research, 37(4), 2523-2557. https://doi.org/10.1111/1911-3846.12588

Jagdambe, S., \& Kannan, E. (2020). Effects of ASEAN-India Free Trade Agreement on agricultural trade: The gravity model approach. World Development Perspectives, 19, Article 100212. https://doi.org/10.1016/j.wdp.2020.100212

Kabir, M., Salim, R., \& Al-Mawali, N. (2017). The gravity model and trade flows: Recent developments in econometric modeling and empirical evidence. Economic Analysis and Policy, 56, 60-71. https://doi.org/10.1016/j.eap.2017.08.005

Kao, C. (1999). Spurious regression and residual-based tests for cointegration in panel data. Journal of Econometrics, 90(1), 1-44. https://doi.org/10.1016/S0304-4076(98)00023-2

Kahouli, B. (2016). Regional integration agreements, trade flows and economic crisis: A static and dynamic gravity model. International Economic Journal, 30(4), 450-475. https://doi.org/10.1 080/10168737.2016.1204338

Kahouli, B., \& Maktouf, S. (2015). Trade creation and diversion effects in the Mediterranean area: Econometric analysis by gravity model. Journal of International Trade \& Economic Development, 24(1), 76-104. https://doi.org/10.1080/09638199.2013.873479 
Kahouli, B., \& Omri, A. (2017). Foreign direct investment, foreign trade and environment: New evidence from simultaneous-equation system of gravity models. Research in International Business and Finance, 42, 353-364. https://doi.org/10.1016/j.ribaf.2017.07.161

Kerr, W. A. (2020). The COVID-19 pandemic and agriculture: Short-and long-run implications for international trade relations. Canadian Journal of Agricultural Economics, 68(2), 225-229. https://doi.org/10.1111/cjag.12230

Kerr, W. A. (2021). Agriculture after a year with COVID-19: Any long-term implications for international trade policy? Canadian Journal of Agricultural Economics, 69(2), 261-267. https://doi.org/10.1111/cjag.12274

Khurana, R., \& Nauriyal, D.K. (2017). ASEAN-India free trade agreement: Evaluating trade creation and trade diversion effects. Journal of East-West Business, 23(3), 283-307. https://doi.org/ 10.1080/10669868.2017.1322548

Lavoratori, K., Mariotti, S., \& Piscitello, L. (2020). The role of geographical and temporary proximity in MNEs' location and intra-firm co-location choices. Regional Studies, 54(10), 14421456. https://doi.org/10.1080/00343404.2020.1732901

Lee, H.L., \& Whang, S. (2005). Higher supply chain security with lower cost: Lessons from total quality management. International Journal of Production Economics, 96(3), 289-300. https:// doi.org/10.1016/j.ijpe.2003.06.003

Leng, Z., Shuai, J., Sun, H., Shi, Z., \& Wang, Z. (2020). Do China's wind energy products have potentials for trade with the "Belt and Road" countries? A gravity model approach. Energy Policy, 137, Article 111172. https://doi.org/10.1016/j.enpol.2019.111172

Lohani, K.K. (2020). Trade flow of India with BRICS countries: A gravity model approach. Global Business Review. Advance online publication. https://doi.org/10.1177/0972150920927684

Lu, C-S., \& Lin, C-C. (2012). Assessment of national logistics competence in Taiwan, Vietnam, and Malaysia. The Asian Journal of Shipping and Logistics, 28(2), 255-274. https://doi. org/10.1016/j.ajsl.2012.08.006

Lyu, G., Chen, L., \& Huo, B. (2019). Logistics resources, capabilities and operational performance: A contingency and configuration approach. Industrial Management \& Data Systems, 119(2), 230-250. https://doi.org/10.1108/IMDS-01-2018-0024

MacDonald, G.K., Brauman, K.A., Sun, S., Carlson, K.M., Cassidy, E.S., Gerber, J.S., \& West, P.C. (2015). Rethinking agricultural trade relationships in an era of globalization. BioScience, 65(3), 275-289. https://doi.org/10.1093/biosci/biu225

Martí, L., \& Puertas, R. (2017). The importance of export logistics and trade costs in emerging economies. Maritime Economics \& Logistics, 19(2), 315-333. https://doi.org/10.1057/ mel.2015.31

Martí, L., Puertas, R., \& García, L. (2014). The importance of the Logistics Performance Index in international trade. Applied Economics, 46(24), 2982-2992. https://doi.org/10.1080/000368 46.2014.916394

Ministry of Industry and Trade (Vietnam). (2020). Vietnam logistics report 2020: Reducing logistics costs. Industry and Trade Publisher.

Morikawa, M. (2019). Firm heterogeneity and international trade in services. World Economy, 42(1), 268-295. https://doi.org/10.1111/twec.12699

Narayan, S., \& Nguyen, T.T. (2016). Does the trade gravity model depend on trading partners? Some evidence from Vietnam and her 54 trading partners. International Review of Economics \& Finance, 41, 220-237. https://doi.org/10.1016/j.iref.2015.08.010

Park, I. (2020). Regional trade agreements in East Asia: Past and future. Development Policy Review, 38(2), 206-225. https://doi.org/10.1111/dpr.12418

Pedroni, P. (1999). Critical values for cointegration tests in heterogeneous panels with multiple regressors. Oxford Bulletin of Economics and Statistics, 61(S1), 653-670. https://doi. org/10.1111/1468-0084.0610s1653 
Pöyhönen, P. (1963). A tentative model for the volume of trade between countries. Weltwirtschaftliches Archiv, 90, 93-100. https://www.jstor.org/stable/40436776

Puertas, R., Martí, L., \& García, L. (2014). Logistics performance and export competitiveness: European experience. Empirica, 41(3), 467-480. https://doi.org/10.1007/s10663-013-9241-z

Qiang, W., Niu, S., Wang, X., Zhang, C., Liu, A., \& Cheng, S. (2020). Evolution of the global agricultural trade network and policy implications for China. Sustainability, 12(1), 192. https://doi. org/10.3390/su12010192

Riadh, H. (2020). Modelling and quantifying the effects of trade facilitation on trade and international transport costs using the logistics performance index. International Journal of Shipping and Transport Logistics, 12(5), 462-486. https://doi.org/10.1504/IJSTL.2020.109888

Roy, S., \& Chatterjee, C. (2013). Dynamics of trade potentials in 'Emerging Asia' in the post financial crisis era. Global Business Review, 14(4), 639-650. https://doi.org/10.1177/ 0972150913501603

Shahriar, S., Qian, L., \& Kea, S. (2019). Determinants of exports in China's meat industry: A gravity model analysis. Emerging Markets Finance and Trade, 55(11), 2544-2565. https://doi.org/10. 1080/1540496X.2019.1578647

Smith, V.H., \& Glauber, J.W. (2020). Trade, policy, and food security. Agricultural Economics, 51(1), 159-171. https://doi.org/10.1111/agec.12547

Stack, M.M., \& Pentecost, E.J. (2011). Regional integration and trade: A panel cointegration approach to estimating the gravity model. Journal of International Trade \& Economic Development, 20(1), 53-65. https://doi.org/10.1080/09638199.2011.538184

Sunge, R., \& Ngepah, N. (2020). Agricultural trade liberalization, regional trade agreements and agricultural technical efficiency in Africa. Outlook on Agriculture, 49(1), 66-76. https://doi. org/10.1177/0030727019870551

Tang, C. F., \& Abosedra, S. (2019). Logistics performance, exports, and growth: Evidence from Asian economies. Research in Transportation Economics, 78, Article 100743. https://doi. org/10.1016/j.retrec.2019.100743

Tham, S.Y., \& Kam, A.J.Y. (2014). Re-examining the impact of ACFTA on ASEAN's exports of manufactured goods to China. Asian Economic Papers, 13(3), 63-82. https://doi.org/10.1162/ ASEP_a_00292

Tham, S.Y., Goh, S.K., Wong, K.N., \& Fadhli, A. (2018). Bilateral export trade, outward and inward FDI: A dynamic gravity model approach using sectoral data from Malaysia. Emerging Markets Finance and Trade, 54(12), 2718-2735. https://doi.org/10.1080/1540496X.2017.1402176

Tinbergen, J. (1962). Shaping the world economy: Suggestions for an international economic policy. Twentieth Century Fund Press.

Tongzon, J.L., \& Lee, S.Y. (2016). Achieving an ASEAN single shipping market: Shipping and logistics firms' perspective. Maritime Policy \& Management, 43(4), 407-419. https://doi.org/10.1080 /03088839.2015.1105393

UNCTAD. (2016). World investment report 2016: Investor nationality: policy challenges.

UNCTAD. (2020). World investment report 2020: International production beyond the pandemic.

Vinod, H.D., \& Rao, P.M. (2019). Externalities from intra-firm trade by US multinationals. International Advances in Economic Research, 25(4), 389-397. https://doi.org/10.1007/s11294019-09758-z

Westerlund, J. (2005). New simple tests for panel cointegration. Econometric Reviews, 24(3), 297-316. https://doi.org/10.1080/07474930500243019

World Trade Organization (WTO). (2021). Regional trade agreements database. http://rtais.wto. org/UI/PublicMaintainRTAHome.aspx 
